\title{
"If Luther will accept us with our confession ...": The Eucharistic controversy in Calvin's correspondence up to 1546
}

\author{
Alasdair Heron (University of Erlangen-Nürnberg, Germany) ${ }^{1}$ \\ Visiting Professor, Department of Dogmatics and Ethics \\ University of Pretoria
}

\begin{abstract}
The article explores Calvin's attitude to the Eucharistic controversy between Wittenberg and Zurich in the years up till Luther's death in 1546. The main source is Calvin's letters from that period, which cast a differentiated light on his aims, hopes and disappointments on the question as well as on his relations to other leading Reformers. Account is also taken of several recent publications, which suggest revision of some long-standing views in Calvin scholarship.
\end{abstract}

\section{INTRODUCTION}

Early in 1536, at the age of only 26, the young John Calvin published the first edition of his Christianae Religionis Institutio ${ }^{2}$ and thereby made his first prominent entrance on the public stage of protestant theology - the setting among other things of the Eucharistic controversy between Luther and his followers and the adherents of Zwingli in Switzerland and southern Germany. It is not therefore surprising that already in this early work Calvin took up a

\footnotetext{
1 Prof Dr Alasdair I C Heron, is Chairperson of Reformed Theology (Lehrstuhl für Reformierte Theologie) at the Institut für Systematische Theologie, Friedrich-Alexander Universität, Erlangen-Nürnberg, Germany. He is a member of the International Advisory Board of HTS Theological Studies and a research associate of Dr Johan Buitendag, Professor in Dogmatics and Christian Ethics, Faculty of Theology, University of Pretoria. Prof Heron presented this paper as guest professor at the University of Pretoria in 2006. It is an expanded version of an essay "'Wenn Luther uns mit unserem Bekenntnis annehmen will': Luther und die Abendmahlsfrage in den Briefen Calvins bis 1546", published in Litz, G \& Munzert, H \& Liebenberg, R (Hrsg) 2005, Frömmigkeit - Theologie - Frömmigkeitstheologie: Contributions to European Church History. Festschrift für Berndt Hamm zum 60.Geburtstag, 395-409. The paper was also presented in a preliminary English form at the Calvin Colloquium in Erskine Seminary in January 2006, but it has since been developed further.
}

\footnotetext{
2 The work was probably completed by the summer of 1535 . At any rate, the dedicatory
} epistle to King Francis I bears the date X Calendas Septembres [1535] (Barth 1926:36). 
stance on the controversy, doing so in the fourth chapter, "Of the Sacraments" (Calvin 1986:104-109). Admittedly he does this without naming the different parties; instead he merely cites various opinions as incompatible with a proper understanding of the presence of Christ in the Supper. ${ }^{3}$ Nevertheless the young French lawyer and humanist scholar enters the debate with a striking independence, reflected in the way he distinguishes between sound teaching and party opinions, however prominent their advocates might be.

Five years later Calvin's Short Treatise on the Holy Supper (Calvin [1541] 1954:140-160) is both more detailed and more direct. Unlike the first Institutio, this work was composed in French and designed for a broad circulation among the francophone protestant churches. At the end of this treatise (Calvin [1541] 1954:160-163) Calvin openly discusses the conflict between Luther and Zwingli, and is not afraid to criticize both. At the same time he confidently expects that the conflict will soon be resolved: God has humbled both parties in order to bring the matter speedily to a happy conclusion.

This optimistic prediction was not of course to be fulfilled. In the Eucharistic question Calvin's Geneva was always in an awkward diplomatic position between Wittenberg and Zurich, not least once the conflict broke out afresh in the last years of Luther's life from 1544 to $1546 .{ }^{4}$ In 1549 after long and strenuous efforts Calvin did succeed with the Consensus Tigurinus in building a bridge between Geneva and Zurich, but he had no success in his hopes of establishing a comparable agreement with Wittenberg.

There is thus a certain similarity between Calvin and Martin Bucer (and, we may add, Philip Melanchthon) in relation to the field of tension between Wittenberg and Zurich, even if the resemblance between Calvin and Bucer turns out on closer examination to be more on the surface. Bucer had already attempted unsuccessfully to mediate between the Lutheran and Zwinglian sides at the Marburg Colloquy in 1529 and tried again repeatedly in the following years, which earned him suspicion and rejection in Zurich to the end of his days. A similar fate befell Melanchthon on the other side. Although in

\footnotetext{
${ }^{3}$ The representatives of these opinions are admittedly not too hard to identify. OS 1 ad loc refers variously to several scholastic theologians as well as to Luther, Erasmus, Zwingli and Schwenckfeld. Battles adds among others Willibald Pirckheimer, De vera Christi carne ... ad Joan. Oecolampadium responsio.

${ }^{4} \mathrm{Cf}$ the later autobiographical retrospective at the beginning of Calvin's Secunda Defensio against Joachim Westphal (1556): When Calvin was beginning to develop a taste for the teaching of the Gospel, he had read in Luther that Zwingli and Oecolampadius acknowledged in the sacraments nothing but mere signs, which long deterred him from reading their works. But even before Calvin himself had begun to write, the two sides had reached a partial understanding in Marburg. Later Luther had spoken positively about Calvin's teaching, as Melanchthon testified. Unfortunately Luther then flared up again in wrath against Zurich (see CO 9, Calvin 1870:51-52).
} 
Marburg he had been decidedly opposed to an agreement, he came to reconsider his position, not least in connexion with the Wittenberg Concord in 1536. This then found expression in 1540 in the Confessio Augustana Variata, to say nothing of his advice in 1560 on the Eucharistic conflict in Heidelberg (Melanchthon 1955:482-486) - but (together with other disagreements with the dominant Lutherans) left him at the end of his life largely marginalized and isolated on the Lutheran side. ${ }^{5}$

It can therefore be of some interest to look in Calvin's letters from the years between the Institutio of 1536 and the Short Treatise of 1541 and again from 1541 to 1546, the year of Luther's death, to see how in these formative years ${ }^{6}$ he thinks about or speaks with or assesses these older reformers, especially Luther, in connexion with the Eucharistic question (Heron 1999:4969). In this as in other respects Calvin's correspondence is a most instructive source, deserving more attention than it is sometimes given. ${ }^{7}$

\section{GENEVA 1536-1538}

Three significant stations in relation to the Eucharistic question during Calvin's first period in Geneva were:

\footnotetext{
${ }^{5}$ On Melanchthon's complex relation to Calvin and Calvinism see for example the papers of the conference on the theme held in Bretten in 2001 (Frank \& Selderhuis 2005). For Bucer's often difficult position up to the years with which the present paper is concerned, see the fruits of a conference in Strasbourg in 2001 (Arnold \& Hamm 2003).

${ }^{6}$ Formative at any rate in regard to his personal career, his experience in church leadership and practical organization, his development as a theological author and his entrance into the world of European ecclesiastical diplomacy. By contrast his specific understanding of the Lord's Supper seems already to have been firmly established by the 1536 Institutio. As he wrote in the letter of $12^{\text {th }}$ January 1538 to Bucer to which we come below, he is conscious "that since I began to taste his Word, God has never so abandoned me that I did not think in an orthodox way of the use of the sacraments and our participation in the body of Christ" (5960). From the very beginning Calvin was neither Lutheran nor Zwinglian, but had ever and again - to his own sorrow and sometimes despair - to concern himself with their conflicts.

${ }^{7}$ In this article I chiefly use the German selection by Rudolf Schwarz, Johannes Calvins Lebenswerk in seinen Briefen: Eine Auswahl von Briefen Calvins in deutscher Übersetzung, first published in two volumes, Tübingen 1909, reprinted in three volumes, Neukirchen 1961, vol 1, to 1547; 1962, vol 2 to 1548-1555; vol 3 to 1556-1564). The page references given in brackets after quotations from Calvin's letters are to this reprint. Schwarz' selection (in all, 759 letters between 1531 and 1564) may appear limited by comparison with the more than four thousand letters and documents contained in CO10/2-20, but CO include many letters to Calvin and some about him as well as other material illuminating aspects of his correspondence. Even at that, not everything in Schwarz is of equal importance or interest; a much reduced selection, containing perhaps a fifth of the letters in Schwarz, is planned as one of the next volumes of the Calvin-Studienausgabe edited by E Busch and others and published by Neukirchener Verlag. I have not to date been able to compare Schwarz with the earlier nineteenth century selection by Bonnet, which appeared first in French and then in English, but hope to do so as part of further work in this area.
} 
- The disputation at Lausanne in the autumn of 1536. Here Calvin intervened twice, on the $5^{\text {th }}$ and $7^{\text {th }}$ October, with one longer and one shorter contribution on the history of the interpretation of the Lord's Supper. ${ }^{8}$

- The suggestions for the celebration of the communion service in the Articles presented by the preachers proposing the reordering of the Genevan Church (Calvin [1537] 1954:47-55), which in respect of the Lord's Supper are very much in line with the suggestions already put forward in the1536 Institutio. ${ }^{9}$

- $\quad$ The discussions at the Synod of Bern in September 1537 on Bucer's and Wolfgang Capito's negotiations with Wittenberg and the Wittenberg Concord. Calvin and Guillaume Farel had been invited at Bucer's request because he had been criticised from the Zwinglian side. In Bern they drafted a short confessional statement on the Eucharist, which the two Strasbourg reformers subscribed (Calvin [1537] 1954:167-169). In Bern itself, however, this had the effect of strengthening the position of the more "Lutheran"10 ministers Peter

\footnotetext{
${ }^{8}$ Cf CO 9, liii-liv on the Lausanne Articles; ibid, 701-702 for the text of the articles. Calvin's interventions are to be found in CO 9, 877-890; Calvin, Theological Treatises, 38-46. It is hard to know how important Calvin's role at the disputation actually was, for it fell in the early months of his initially modest beginnings in Geneva. The disputation was however both positively and negatively significant for him, for here he began or deepened his friendship with Pierre Viret, who along with Farel was to become his closest ally for the rest of his life, and experienced the confrontation with Pierre Caroli, which was to reverberate through Calvin's letters and other writings in the following years.

\begin{abstract}
${ }^{9}$ This does not necessarily imply the correctness of the almost universal opinion in modern research that Calvin was the real author of the 1537 Articles (or at least chiefly responsible, as is still accepted for example by Peter Opitz in his introduction to the Articles in the CalvinStudienausgabe, edited by E Busch et al, vol 11 , Neukirchen 1994:109-110). Since then, strong arguments for ascribing them mainly to Farel - based partly on the use of language, partly on points of content and parallels to other writings of Farel's and partly on what can be suspected about the probable relationship between Farel and Calvin in the first months of Calvin's time in Geneva - have been advanced by Frans Pieter van Stam (2000), "Die Genfer Artikel vom Januar 1537: Aus Calvins oder Farels Feder?" Zwingliana XXVII, 87-101.
\end{abstract}

\footnotetext{
${ }^{10}$ At least, they have generally been described as "Lutheran" in the tradition of research initiated by Carl Bernhard Hundeshagen (1842), Die Conflicte des Zwinglianismus, Luthertums und Calvinismus in der bernischen Landeskirche von 1532-1558, Bern 1842. The label has, however, recently been challenged by Amy Nelson Burnett (2005), "The Myth of the Swiss Lutherans: Martin Bucer and the Eucharistic Controversy in Bern". Zwingliana XXXII, 45-70. She argues persuasively that the so-called "Lutherans" really inclined more to Bucer's theology - which also of course casts a rather different light on the balance of forces during and after the Bern Synod in 1537 (cf also Cornelis Augustijn [2003], "Farel und Calvin in Bern 1537-1538", in Peter Opitz [Hrsg], Calvin im Kontext der Schweizer Reformation, Zurich, pp 923).
} 
Kuntz ${ }^{11}$ and Sebastian Meyer and contributing - at least indirectly - to the dismissal of the Zwinglian Caspar Megander only months later, though the other, less sharply profiled Zwinglian Erasmus Ritter remained in office.

Against this background two of Calvin's letters in the early months of 1538 deserve special attention. The first is to Bucer in Strasbourg and deals fairly extensively with the Eucharistic question - and also more than somewhat critically with Bucer's mediating tactics. The second went to Bullinger in Zurich and touches more briefly on Luther and the current state of the debate. Calvin wrote on $12^{\text {th }}$ January 1538 to Bucer (Schwarz 1961, Briefe, 15, 58-64; CO 10/2, Brunswick 1872, Ep 87, 137-144) (Augustijn 1997:155170). ${ }^{12}$ It is just three months since the Synod of Bern. Megander has been

\footnotetext{
${ }^{11}$ Calvin complains frequently about Kuntz (or Kunz) in the following years, both before and after his own expulsion from Geneva (cf the register of names in Schwarz, Briefe, vol 3, 12831210. It would seem that the two found each other so mutually unsympathetic that conflict was pre-programmed. An interesting light is cast on this by a quite emotionally coloured appeal sent by Simon Grynaeus in Basel to Farel and Calvin on the $4^{\text {th }}$ March 1538 (CO 10/2, Brunswick 1872, Ep 97, 158-161). Christoph Burger (2003), "Calvins Beziehungen zu Weggefährten in der Schweiz", in Peter Opitz (Hrsg), Calvin im Kontext der schweizer Reformation, Zurich, pp 41-55, summarises Grynaeus' letters to Calvin on pp 50-53, coming on pp 52-53 to this letter of 4 th March 1538. Freely translated Burger's synopsis reads: "Grynaeus wrote again on March 4th to Farel and Calvin. In the address Farel is again named here before Calvin. Since, however, in the text of the letter Grynaeus addressed Calvin seven times, but wrote of Farel in the $3^{\text {rd }}$ person singular, he obviously meant to deal with Calvin. Only at the beginning and end of the letter did he speak warningly to both addressees. This letter is significantly longer than the others. Grynaeus calls on Calvin to put aside his conflict with the Bern ministers Peter Kuntz and Sebastian Meyer. Since Megander's dismissal Kunz was the dominant minister in Bern. Once again, Grynaeus named the devil the real manipulator of the conflict. But with that he did not in any way intend to excuse Calvin. Calvin should rather make peace with Kunz. The Bernese, wrote Grynaeus, had written positively about Farel and Calvin. Calvin by contrast had reported very hostilely about Kunz. He must have done that either in a letter that has since been lost or in one to the ministers in Strasbourg which was sent via Basel and which Grynaeus thus got to read. Within certain limits Grynaeus shows understanding for Calvin's annoyance: Kunz tramps about like a coarse peasant, he admits. That doesn't surprise him either, for Kunz comes from Simmental, whereas Calvin had enjoyed a far more careful upbringing. But Kunz is a pious man who works hard for God's church. And that is what counts. At the moment, Grynaeus reproaches Calvin, he is coming on even harder than Farel, who otherwise can be so impetuous. He should follow Farel's example, become milder and be reconciled with Kunz. He should for once try to regard Kunz as a brother and interpret his qualities in a better light. Only in unity can the wolves be resisted who seek to swallow up the flock of Christ. At the synod in Bern in September 1537 Calvin and Kunz had given Grynaeus the impression that they had been reconciled. Calvin as the better brought up of the two should give way and accept Kunz as he is. Grynaeus' reproach of Calvin is very apparent in this letter."
}

\footnotetext{
${ }^{12}$ The letter and its implications for the development of Calvin's relationship to Bucer are also touched on in Augustijn's (1994:166-177) earlier contribution.
} 
dismissed, which has greatly shocked Calvin ${ }^{13}$ and led him to wonder whether the effort to find unity with the Lutherans may not demand much too high a price. ${ }^{14} \mathrm{He}$ touches on the suspicions that many entertain about Luther's teaching, specifically mentioning "changing" of the elements, a fictional "unlimitedness" of the body of Christ or its "local presence" in the Supper. Luther's own former way of speaking had given ample occasion for such suspicions. These must now be cleared away - which Calvin apparently regards as quite realistically possible. Then he comes to Luther's own person (p 59):

If Luther will accept us with our confession, there is nothing I could wish for more. But he is not the only one to be respected in the Church of God. We must be threefold cruel dolts if we ignored the many thousands who would be hatefully injured by such a union. I do not know what I should think of Luther, although I am firmly convinced of his genuine piety. If it were only not true ... that there is a good measure of obstinacy mixed in with his steadfastness in faith! He himself gives no little occasion for this suspicion. If it is true, as I recently heard, that the word is swirling through all the Wittenberg churches that they have now brought almost all other churches to recognise their error, what kind of vanity is that!

It is not self-congratulatory declarations of victory that are now required, but genuine efforts at reaching understanding, the setting aside of animosities and the correction of misleading and misunderstood formulations. So Calvin appeals to Bucer to intervene with Luther, but also goes on to criticise Bucer's own tactics (pp 59-60):

So if you can achieve anything with Luther through favour or respect, try to see that he subordinates his opponents in this unholy struggle to Christ rather than his own person and that he stretches out his own hand to the truth where he is in conflict with it. ... What matters is that each should honestly recognise his error; and I could not avoid testifying to you, as you will remember, that the obsequious way in which you tried to excuse Zwingli and yourself displeased me. ... If you demand from the Swiss that they quickly

\footnotetext{
${ }^{13}$ The immediate occasion was Bucer's revision of Megander's Catechism along the lines of the Bern Synod. Megander's vigorous protests led to his dismissal. Calvin knows of this and mentions it in the letter to Bucer, though only in passing. He does not lay charges directly against Bucer, but makes no secret of his sympathy for Megander. On Bucer's revision of Megander's text (cf Henrich 1997:81-94).

${ }^{14}$ With a characteristic lack of understatement Calvin visualises "the bloody sacrifice of many pious men" (p 58).
} 
put away their obstinacy, then work on Luther as well to make him stop behaving so imperiously.

A clear message both for Luther and for Bucer! Calvin goes on to discuss the situation in Bern, but then returns to a lengthy and detailed critique of Bucer's style of mediation (62-64) - a critique which in view of Bucer's seniority in age and experience may well seem surprisingly brusque on Calvin's part, but for which he claims the support of his colleagues in Geneva ( $p$ 62):

But it seems to us ( $\mathrm{l}$ am speaking in my own name and those of my colleagues) that you too require a warning. ... In handling the divine Word, particularly in the current controversial matters, you attempt to tune your voice so that you will give no-one offence. We are convinced that you do this with the best intentions. Nevertheless we must disapprove of your efforts

Calvin first charges Bucer with being all too ambiguous in discussion with representatives of Rome, which in the end can only confuse the simple who are so dear to Bucer's heart. "You began with this in your commentary on the Psalms, ${ }^{15}$ a work of otherwise unequalled excellence, but this subtlety which it would be wrong to call pious has always been held against you. To be quite honest, I always found it intolerable that you totally destroyed justification by faith" (pp 62-63).

In spite of all its learning, art and industry Bucer's little book against Cenalis (Bucer 1534:143) "is marked by so many dark stains that most people would prefer to see it corrected by scoring a line through the whole", which "would probably be your judgment too if you knew what fruits this writing bears in England and France. In everything you have published since there is something of this odious yeast mixed in" ( $p$ 63). Even worse - and now Calvin comes back to relations with the Lutherans - this stance even threatens to discredit Bucer's mediation between the Upper Germans and Luther in Luther's eyes ( $p$ 63):

To be sure, I have always admired the intention of your mediating task. For when you warn us to seek unity with Luther, you value that so highly that you insist nothing must be worth more to us than to combat Satan's lies with united hearts and weapons. In this moderation you are so unlike Luther that I believe your tactics will infuriate him even more than the views of Zwingli and

\footnotetext{
${ }^{15}$ This commentary appeared in 1529 under the name Aretius Felinus. On the significance of this pseudonym and of the pretended place of publication in Lyons cf Bucer's letters to Zwingli in the summer of 1529 in (Bucer 1995, SMRT 56, pp 261-263, n 223 and 299 f, n 239).
} 
Oecolampadius. For he never fought so bitterly against the sacramentarians as when he charged them with destroying the righteousness that comes from faith, or at least downgrading and obscuring it.

Just at this time, however, Calvin has other worries. The storm clouds are gathering over Geneva; in April 1538 Calvin will in fact be dismissed along with Farel and Elie Coraut. On $21^{\text {st }}$ February Calvin writes to Heinrich Bullinger, chiefly about his vision of a healthy ordering of the Genevan church (Schwarz 1961:93, 153-154).

At the end, however, he refers briefly to a letter from Luther: "Pellikan has told us you have had a most gracious and friendly answer from Luther. Grynaeus also says that he sees in this great hope of making peace with the other side. We have not had a word from the church that because of its proximity could most easily have informed us. Do take the trouble to sketch at least the main contents when you can" (p 65).

Luther had indeed written as early as the $1^{\text {st }}$ December to "the honourable, farsighted Lords, Mayors, Magistrates, Bailiffs and Citizens of all the confederate cities, Zurich, Bern, Basel, Schaffhausen, St Gallen, Mühlhausen and Biel, my especially favourable masters and good friends" (Luther 1983:234-236). He pleads here for acceptance of the Wittenberg Concord and replies to articles which the Swiss had presented to him (pp 235236):

The third article, of the sacrament of the body and blood of Christ: We have never ever taught, and still do not teach, that Christ descends from or ascends to heaven or the right hand of God, neither visibly nor invisibly; stand for our part by the article of the creed: "Ascended into heaven, Sits at the right hand of God, Will in the future etc.", and leave to the divine omnipotence how his body and blood are given to us in bread and the Supper when we come together as he commanded and observe his institution.

This clears away at least part of the misunderstandings that Calvin had traced back to imprecise formulations on the Lutheran side. In addition the entire tone of Luther's letter is exceedingly conciliatory and accommodating. In particular he expresses his confidence in the capacity of Bucer and Capito "to mediate herein plainly and clearly and to explain everything in the best possible way" (235). ${ }^{16}$ One may imagine that Calvin at any rate could have

\footnotetext{
${ }^{16}$ This was admittedly not perhaps best designed to scatter the doubts of the Swiss! - That apart, it may be added that such a positive estimate of Bucer as appears in this letter is not exactly typical of Luther (cf de Laharpe 2003:147-156)!
} 
been at least half-way satisfied with this response - but not the hard-line Zwinglians, especially in view of the unclarity which "leaves to the divine omnipotence how his body and blood are given". ${ }^{17}$

\section{STRASBOURG 1538-1541}

This last suspicion is confirmed fifteen months after the letter to Bullinger in a message from Calvin to André Zébédée on $19^{\text {th }}$ May 1539. After the first restless months following his expulsion from Geneva, Calvin had now been settled for something more than half a year in Strasbourg. He had also accompanied Bucer in the spring of 1539 to the convention of the German Imperial Estates in Frankfurt, getting to know Melanchthon and gaining insight at first hand into the politics of the Empire and the goals of the Schmalkaldic League (cf Stolk 2000:23-38). ${ }^{18}$ Zébédée was minister in Orbe, an enthusiastic admirer of Zwingli and a decided opponent of attempts to achieve unity with the Lutherans. He was at the same time a man of learning and ability and a good Latinist (and in 1546 became professor in Lausanne). ${ }^{19} \mathrm{His}$ convictions were clearly expressed a little later, for example, in a Latin poem penned by him, which Rudolf Gualther sent to Bullinger in December of 1539. ${ }^{20}$ Roughly translated, the lines on Zwingli run: "To expect one greater is

\footnotetext{
${ }^{17}$ The expression here calls to mind the words ascribed to Queen Elizabeth I when faced some years later with similar debates in the Church of England: "He took the bread and brake it/And what his word doth make it/That I believe and take it."

${ }^{18}$ After returning to Strasbourg Calvin gave Farel a detailed account of the convention in four letters in March and April 1539 (CO 10/2, Ep 162; 164; 168; 169; Schwarz 1961, Briefe, n 32$35,105-116$. Here too - though not without personal sympathy for their aims - Calvin registers doubts about the soft or even ambiguous positions taken by Bucer (and Melanchthon) over against the Roman side. In the fourth of these letters he refers to Zébédée's reservations (Schwarz 1961:115) while himself stressing the advantages for the Upper Germans of an alliance with the Schmalcaldic League in view of the tactics of the Emperor. Similarly, two years later in 1541 in Regensburg, Calvin writes to Farel of his doubts about Bucer's and Melanchthon's strategy and fears that Bucer will only earn more animosity by it (cf CO 11, Brunswick 1873, Ep 309, 217-218; Schwarz 1961, Briefe n 69, 192-193. For a more detailed account of Bucer's endeavours in 1540/1541 at Hagenau, Worms and Regensburg, see Ortmann 2003:127-146).
}

${ }^{19}$ Zébédée was also one of those who urged Calvin to return to Geneva once the city council had voted on $21^{\text {st }}$ September 1540 to recall him. Cf his letter to Calvin on $1^{\text {st }}$ October 1540 (in CO 10/2, Ep 171, 344-347).

${ }^{20} \mathrm{CO} 11,24, \mathrm{n} 7$ gives an excerpt from Gualther's letter and the Latin text of the verse on Zwingli:

Maiorem sperare nefas: fortasse petendum Ut dent vel unum saecula nostra parem. Os doctum, pectus sincerum, spiritus acer, Unius in laudes incubuere Dei. 
sin. Perhaps we may pray the century yet may bring one such other to match him. The learned words of his mouth, uprightness of heart together with

So I shall not cease to praise Bucer's industry, which I also believe I can clearly recognise in Melanchthon. Certainly I admit that I too could wish some things different in him; I am far from wishing anyone to take an unconditional oath on his words. My desire is only this: that we should give up all hampering prejudices, quietly listen back and forth, and postpone the decision on the facts until we have found the truth. - You do not need to upset yourself so much that Bucer has taken back things he previously said. As he had erred in his statements on the significance of the sacrament he was right to withdraw them. Indeed, if only Zwingli had decided to do the same, for his view of the matter was as false as it was dangerous! ${ }^{21}$ When I was still in France and saw how many of our people heard his view with applause, I opposed it openly. It is certainly mistaken for Bucer - this I do admit - to try to soften Zwingli's and Oecolampadius' opinion so that he almost makes them agree with Luther. But it is just this objection that is not raised by those who otherwise hatefully exaggerate everything else about him, for nothing is dearer to their hearts than that Zwingli is left without reproach. I would rather prefer them to abandon such anxious apologetics and give God the glory by simply admitting the truth. I do not in any way concede to you that there is nothing questionable in Zwingli's teaching. For it is easy to see that he was too much concerned to root out superstitious belief in the fleshly presence of Christ and surrendered or at least seriously obscured the true power of [our] communion [with him]. It rightly annoys you that Luther himself takes absolutely nothing back, moderates nothing and obstinately clings to everything. But what should Bucer do? You say he should have waited. Yet it was better to give Luther and the others an example to remind them of their duty. Why all the holy indignation? When he has renounced his own errors, then he can challenge the others in God's name to improve for their part what they had wrongly said ( $p p$ 117-118).

Ten months later Calvin speaks even more sharply in a letter to Farel on $26^{\text {th }}$ February 1540 (Schwarz 1961, Briefe, n 45, 140-142; CO 11, Ep 211, 23-26), after he too had now heard of Zébédée's poem ( $p$ 140):

\footnotetext{
${ }^{21}$ On this and Calvin's other occasional comments on Zwingli (cf Blanke 1960:18-47). Blanke also reports in this paper (Aus der Welt der Reformation, pp 35-38) on certain repercussions of this remark in the letter to Zébédée fifteen years later when Zébédée, now minister in Nyon, used it against Calvin. Calvin protested to the council of Bern, which, however, took Zébédée's side, as Calvin complained in a letter to Bullinger (CO 15, 572-573). He wanted Bullinger to reassure the Bernese that Calvin's letter to Zébédée did not anger Zurich, but Bullinger does not appear to have reacted.
} 
These good people [in Zurich] immediately flare up in wrath when anyone dares to prefer Luther to their Zwingli. As if the Gospel would go under if Zwingli were injured! And yet Zwingli does not suffer the least injustice by it; you know yourself how far Luther surpasses him when the two are compared. So Zébédée's poem does not please me at all when he thinks that he cannot praise Zwingli as he deserved without saying, "To expect one greater is sin". ... There is a proper measure to be observed in praising and Zébédée has gone far over the score. I at least am very far from agreeing with him; rather I can even now see many who are greater, anticipate yet others, indeed I wish us all to be greater. ... But that is only for your ears.

Such high regard for Luther is nothing new for Calvin. One may, however, suspect that it was also strengthened by a pleasant surprise a few months earlier, in the autumn of 1539 . Luther had written to Bucer on $14^{\text {th }}$ October and in closing had spoken very warmly of Johannes Sturm - and of Calvin. ${ }^{22}$ Calvin himself had reported this in an earlier letter (Schwarz 1961, Briefe, $\mathrm{n}$ 43, 136-137; CO 10/2, Ep 197, 429-432) to Farel on 20 ${ }^{\text {th }}$ November 1539 (pp 136-137):

One of our printers, Krafft, recently came back from Wittenberg and brought with him a letter of Luther's to Bucer, in which stood, "Greet Sturm and Calvin with my respects; I have read their books with deep satisfaction." Now remember what I said there about the Lord's Supper and consider how honourable Luther is being. It is easy now to see how little ground those have, who so obstinately keep their distance from him. And Philip [Melanchthon] wrote: "Luther and Pommer [Johannes Bugenhagen] send greetings to Calvin and Sturm. Calvin is come into great favour." Melanchthon also had the messenger tell how an attempt was made to stir Luther up by showing him how sharply I had criticised him and his people. So he looked at the passage more closely and saw that it was without doubt aimed at him. Finally he said, "I hope he [Calvin] will one day think better of us; but it is only right that we should

\footnotetext{
${ }^{22}$ Luther's words are given in CO 10/2, Ep 190, 402: "Bene vale. Et salutabis D lohannem Sturmium et Joh Calvinum reverenter, quorum libellos cum singulari voluptate legi. Sadoleto optarem ut crederet Deum esse creatorem hominum etiam extra Italiam. Sed haec persuasio non penetrat corda Italorum ...". The reference to Sadoleto is understood by the editors of CO to mean that Luther is not referring to Calvin's position on the Lord's Supper, but to his Epistula ad Sadoletum and to Sturm's Epistolae de dissidiis religionis. That may be so, but both Calvin's reference and the additional comment by Melanchthon would seem to suggest strongly that the Eucharistic question was also in play.
} 
occasionally tolerate criticism from so able a spirit." ${ }^{23}$ We would really have to be made of stone if we were not overwhelmed by such restraint. I am overwhelmed. So I have written something to please him; it is to be inserted in the foreword to the Letter to the Romans. $^{24}$

\section{GENEVA 1541 TILL LUTHER'S DEATH IN 1546}

On his return to Geneva in the autumn of 1541 Calvin found himself confronted with a whole range of tasks and challenges that drove the disagreements between Wittenberg and Zurich somewhat into the background. Up to the spring of 1544 the controverted themes mostly appear in his letters in connexion with an upsurge of Zwinglianism in Bern, which manifestly displeases him (Schwarz 1961, Briefe, n 91, 228-229; n 92, 229232; CO 11, Ep 417, 430-432; Ep 421, 436-439).

There were also questions from reformed ministers in the county of Montbéliard in view of the introduction of "Lutheran ceremonies" by Duke Christopher of Württemberg. Calvin takes great care to give sensible and differentiated replies to these questions (Schwarz 1961, Briefe, n 103, 253255; n 113, 270-273; CO 11, Ep 506, 623-626; Ep 547, 704-708) (see also Schwarz 1961, Briefe, n 117, 277-279; CO 11, Ep 575, 751-754) and particularly emphasises what he still applauds as Luther's moderation. So he writes to Montbéliard on $8^{\text {th }}$ May 1544 ( $p$ 270):

Just as in our time the Gospel went out from the church in Wittenberg, so now there are people coming from there who are not unlike those who once sallied forth from Jerusalem and wherever they went caused trouble for the true servants of Christ and sought occasion to provoke uproar. ... I say this so that no-one's affection is turned away from the church in Wittenberg. ... I dare to assert for

\footnotetext{
${ }^{23}$ There seems no reason to doubt the reliability of this additional information from Melanchthon, and it was clearly of great personal importance for Calvin. It does however remain at best indirect evidence for Luther's attitude. The same applies to the oft-quoted anecdote recorded in Pezel's Erzählung vom Sakramentsstreit (reproduced by A Barclay 1927:137f) about Luther's reaction to the Petit Traicté: "The book of Calvin translated into Latin by des Gallars had been printed in 1545 , and brought to Wittenberg. On $13^{\text {th }} \mathrm{April}$, Dr Luther, having finished his lecture, betook himself to the bookshop of Moritz Goltsch, who showed him Calvin's little work on the Lord's Supper. Dr Luther, seating himself, read the book with particular interest, and at last said, 'Certainly a learned and pious man! I could have entrusted the whole matter of this debate to him. For my part, I consider that if the opposite party had not made so much of it, we could have come to an agreement. If Zwingli and Oekolampadius had expressed themselves thus at the beginning, we should not have had so long dispute."'

${ }^{24}$ The text of this excusatio is given in Herminjard (1966:127-132). On Melanchthon's advice, however, it was not inserted in the Romans foreword, but its material did find its way into later editions of the Institutio (cf Kuropka 2003:147-167, esp pp 163-166).
} 
certain that those braggarts who misuse the name of that church in this way ... displease Luther no less than us.

A few days before, admittedly, writing to Melanchthon on $21^{\text {st }}$ April (Schwarz, Briefe, n 112, 268-270; CO 11, Ep 544, 696-698) Calvin had had renewed cause to express worry over Luther's behaviour ( $p$ 269):

\begin{abstract}
Bullinger has recently complained to me that Luther has once again cruelly demolished everyone in Zurich. He sent me a copy of the letter, and I too find it totally lacking in propriety. ${ }^{25} \mathrm{I}$ beg of you, hold Dr. Martin back as well as you can, or rather stop him from giving in to his rage against the church in Zurich. He may have reason to be angry with them, but pious and learned men ought nevertheless to be treated more politely.
\end{abstract}

However, we are here already on the threshold of a new eruption by Luther: his Short Confession of the Lord's Supper in September 1544. After its publication Farel urged Calvin to travel to Zurich and warn the colleagues there to keep the peace. Calvin replied on $10^{\text {th }}$ October (Schwarz 1961, Briefe, $n$ 118, 279-280; CO 11, Ep 567, 754-755) that it would be pointless ( $p$ 280):

For it is not from them that danger threatens, but from Luther. He is the one who needs to be calmed down. Or should we somehow extort from Zurich that they humbly beg Luther for pardon? ... So let us call on the Lord, for he alone can heal this evil.

Nevertheless Calvin did write to Bullinger on $25^{\text {th }}$ November (Schwarz 1961, Briefe, n 120, 285-286; CO 11, Ep 586, 772-775) to urge Zurich to be tolerant and make allowances for Luther's temperament. He writes among other things (p 285):

\footnotetext{
${ }^{25}$ What Calvin had heard from Bullinger was presumably similar to what Bullinger wrote in a letter to Vadian in May 1544 (CO 11, Ep 555, pp 722-724). Luther's letter was indeed quite as intemperately aggressive as Calvin suggests. It had been written on $31^{\text {st }}$ August 1543 to "thank" the Zurich printer Christopher Froschauer for a copy of the Zurich Bible, but the thanks were accompanied by an unrestrained denunciation of the Zurich theologians, whom Luther declined to join on their road to hell and whose works he no longer wished to be sent. The full text is given in (Luther [1543] 1983:285-286).
} 
Quite apart from his own immoderately passionate and disrespectful character, Luther also has Amsdorf ${ }^{26}$ as his adviser, an absolutely crazy fellow without a brain, and allows himself to be steered or rather driven astray by him. ... I do not know whether Luther was provoked by some writing from your side; but even if a character like his - which is not only irritable but embittered - flares up at the slightest occasion, he can certainly still have no grounds for such storming and raving. ... But it is still my wish that you consider what a great man Luther nevertheless is, with what exceptional spiritual gifts he is adorned, how bravely and unshakeably, how adroitly and effectively he has always worked till now to break the rule of the Antichrist and spread the doctrine of salvation. I have already said it often enough: even if he were to call me a devil I would still do him the honour of regarding him as a quite outstanding servant of God.

Calvin apparently does not see himself as the target of Luther's attack, however regrettable in his eyes both Luther's unwillingness for conciliation and the corresponding Zurich attitude may be. We can see both aspects, for example, in two letters Calvin sent just a few weeks later, in January 1545, asking Luther and Melanchthon to express a judgment supporting his admonitions to the French Nicodemites (Schwarz 1961, Briefe, n 122, 288289; CO 12, Brunswick 1874, Ep 605, 6-8) (Schwarz 1961, Briefe, n 123, 289291; CO 12, Ep 606, 9-12).

Here he addresses Luther with the utmost respect: "To the excellent shepherd of the Christian church, Dr. Martin Luther, my highly honoured father, greeting. ... Farewell you highly famed man, most excellent servant of Christ and ever my respected father" (pp 288-289) - but leaves it to Melanchthon to decide whether or not to show Luther the letter (Melanchthon did not):

With Dr. Martin it will be somewhat more difficult. As far as I can gather from hearsay and from letters of individual persons it is very likely possible that his scarcely reconciled temper could be irritated afresh by some slight cause. ... I have only heard that a terribly

\footnotetext{
${ }^{26}$ Calvin had experienced Amsdorf at first hand at the Colloquy in Regensburg in 1541 (cf Calvin's letter to the ministers in Zurich on $13^{\text {th }}$ November 1554; Schwarz 1961, Briefe, $n 422$, 720-722; CO 15, Ep 2042, pp 303-307). There he looks back to the colloquy and refers specifically to Amsdorf's unsuccessful objection to the modification of the Lutheran position in the Confessio Augustana Variata. On other occasions, too, the references to Amsdorf in Calvin's letters are less than flattering. Cf e.g. Schwarz 1961, Briefe, n 282, pp 495-497 (CO 13, Ep 1297, pp 437-440), written in October 1549 to Bucer in Lambeth in defence of the Consensus Tigurinus: "To tell the truth, the doctrine of the Papists was more moderate and sober than what Amsdorf and his like brought forward. They raved like prophesying Delphic priestesses" ( $p$ 497).
} 
sharp writing (cf CO 12, $10 \mathrm{n}$ 12) has appeared which will burn like a torch to rekindle the conflagration unless the Lord restrains the spirits of the other party, who as you know are also more passionate and full of themselves than they should be. ... Because [the brothers in] Zurich have up to now shown me a certain goodwill, I attempted to mediate as soon as I heard of the matter and asked them not to let themselves in for a fight. ... But as since then I have had no further letter from Zurich I fear the worst (pp 290-291).

Calvin will thus still try to judge both sides as fairly as possible and will for his part undertake nothing that might make the situation even worse. He was all the more disappointed when in the following months Zurich replied sharply to Luther and Luther fired even more hotly back. On the $28^{\text {th }}$ June 1545 Calvin writes to Melanchthon (Schwarz 1961, Briefe, n 135, 308-309; CO 12, Ep 657, pp 98-100), exasperated with both sides - and deeply disillusioned by what he sees as Melanchthon's weakness in the whole affair. Those in Zurich, he says (pp 308-309):

... excuse and defend ... their Zwingli with more obstinacy than learning and sometimes with too little modesty. In Luther they exaggerate some things unfairly; but in particular they have gone forward most unfortunately, in my opinion, in the main point, that is in that on which the whole matter turns. ... Zurich certainly made a bad beginning; but where does your Pericles allow himself to be driven in his unrestrained, thunderbolt-hurling rage? Particularly as his case is no whit better. And what does such roaring achieve, except that the whole world thinks he is crazed? I at least, who do honour him from my heart, am deeply ashamed for him. But the worst of it all is that no-one dares to oppose him in order to prevent such improper behaviour, or even to utter a squeak. ... But if you circumnavigate this particular question like a dangerous cliff, just to avoid annoying certain people, then you leave many more suspended in uncertainty that look to you for something solid to set their minds at rest.

Calvin's disappointment is evident. However, his fundamentally positive attitude to Luther in spite of all criticisms is expressed again in the following spring. This is in a letter of $17^{\text {th }}$ March 1546 to Veit Dietrich in Nuremberg (Schwarz 1961, Briefe, n 160, 335-337; CO 12, Ep 781, 315-317), a close friend of Melanchthon and the editor of Luther's Commentary on Genesis. Calvin has not yet heard of Luther's death four weeks before on $18^{\text {th }}$ February. $\mathrm{He}$ is writing to answer a friendly letter dictated on $3^{\text {rd }}$ February by Dietrich in 
Nuremberg. This mainly reported on the colloquy then taking place in Regensburg, but in closing also praised Calvin's Short Treatise on the Lord's Supper, ${ }^{27}$ which had appeared in Latin in 1545 . This leads Calvin to look back on his treatment of the controversial question:

It pleases me greatly that you too were not displeased with my little book on the Supper. It was written ten ${ }^{28}$ years ago in French. .... . The simple, popular style, tailored for uneducated people, shows what my initial aim was. For Latinists I am accustomed to write more carefully. But I did my best not only to express my opinion faithfully and to summarise it briefly, but also to explain it clearly and without obscurity. At the same time the Institute (which I had revised) was published for the second time. There I present the same teaching in another style - if I do not deceive myself, in one that is clearer - and establish it more firmly. Finally I have also published a Catechism, which gives good reliable evidence of the doctrine in which I instruct the church here. If only, as you say, Zurich would attach itself to this confession! I think Luther would not then be so unyielding that a union would not be easy to arrange ( $\mathrm{pp}$ $335-336){ }^{29}$

Perhaps an unrealistic hope, for in view of all we have seen here it might well seem that Calvin's confidence that he could win Luther over was never very

\footnotetext{
${ }^{27}$ Dietrich had written (CO 12, Ep 758, p 266): "Legi conciunculam tuam de sacramento caenae, ac probo quod panem et vinum sic signa vocas, ut signata revera adsint: Utinam possint at te in eam sententiam deduci qui nuda tantum signa reliquerunt." - Calvin and Dietrich may have met at Regensburg in 1541, but too little is known about Dietrich's activity there to allow us to be certain (cf Klaus 1958:188).

${ }^{28}$ Sic! Is Calvin perhaps mixing up the dates of the first Institutio and the Petit Traicté?

${ }^{29}$ Cf Calvin's remarks in a letter of $16^{\text {th }}$ November 1546 (Schwarz 1961, n 184, 361-364; CO 12, Ep 852, pp 418-423) to the Sieur de Falais in Strasbourg about a petition Calvin had drawn up for him: "Something else I had forgotten, namely the charge against me that I wished in the doctrine of the Lord's Supper to see the real body of Christ contained in the bread. I know not how even in a dream one could see anything of the kind in me. I never thought of it. I speak about this question in various writings, mainly in the Institutio, in the Commentaries on the Letters to the Corinthians, and in the treatise on the dispensing of the Supper. In the petition I only touch lightly on this. I do not believe that any reader of judgment will find any contradiction [between my statements]. But that is just it: some believe one cannot distinguish between symbol and reality without totally separating them and so making God a comedian who presents vain falsehoods in a picture. It is our responsibility now to recognise that this comes from the cunning of Satan, who wants to disunite our spirits so that our work will be in vain" (pp 363-364)
} 
well grounded - but it can make one wonder what other things might all have been different "if Luther had accepted us with our confession". ${ }^{30}$

\section{Works consulted}

Arnold, M \& Hamm, B 2003 (Hrsg). Martin Bucer zwischen Luther und Zwingli. Neue Reihe. Tübingen: Mohr-Siebeck.

Augustijn, C 1994. Calvin in Strasbourg, in Neuser, W (ed), Calvinus Sacrae Scripturae Professor. Grand Rapids, MI: Eerdmans.

Augustijn, C 1997. Bern and France: The background to Calvin's letter to Bucer dated January 12, 1538, in Neuser, W (Hrsg), Ordentlich und fruchtbar: FS für Willem van 't Spijker. Leiden: Brill.

Augustijn, C 2003. Farel und Calvin in Bern 1537-1538, in Opitz, P (Hrsg), Calvin im Kontext der Schweizer Reformation. Zurich: Theologischer Verlag.

Barclay, A 1927. The protestant doctrine of the Lord's supper. Glasgow.

Barth, P \& Niesel, G 1926 (Hrsg). Johannis Calvini Opera Selecta, vol 1. Munich: Christian Kaiser Verlag.

Blanke, F 1960. Calvins Urteile über Zwingli. Zwingliana 1958/2, 66-92.

Bucer, M 1534. Defensio adv axioma catholicum i.e. criminationem Roberti ep. Abrincensis.

Burger, C 2003. Calvins Beziehungen zu Weggefährten in der Schweiz, in Opitz, P (Hrsg), Calvin im Kontext der schweizer Reformation. Zurich: Theologischer Verlag.

Burnett, A N 2005. The myth of the dwiss Lutherans: Martin Bucer and the Eucharistic Controversy in Bern. Zwingliana XXXII, 45-70.

Calvin, J 1954. Calvin: Theological treatises, tr with introductions and notes by J K S Reid. London: SCM.

Calvin, J 1986. Institutes of the Christian Religion, tr by F L Battles. Grand Rapids, MI: Eerdmans.

Calvin, J 1870. Ioannis Calvini Opera quae supersunt omnia, vol 9, ed by G Baum et al. Brunswick, NJ: Schwetske.

De Laharpe, N 2003. Bucers Porträt in Luthers Tischreden, in Arnold, M \& Hamm, B (eds), Martin Bucer zwischen Luther und Zwingli. Tübingen: Mohr-Siebeck.

Frank, G \& Selderhuis, H J 2005 (Hrsg). Melanchthon und der Calvinismus. StuttgartBad Cannstatt: Fromman-Holzbog.

Henrich, R 1997. Ein Berner "Kunzechismus" von 1541: Bucers verloren geglaubte Bearbeitung des Meganderschen Katechismus. Zwingliana XXIV, 81-94.

Heron, A I C 1999. Calvin an Bullinger 1536-1549, in Freudenberg M (Hrsg), Profile des Protestantismus aus vier Jahrhunderten. Wuppertal: Foedus.

Herminjard, A L (ed) 1966. Correspondance des Réformateurs dans les pays de langue francaise, 6:1539-1540. Geneva 1883/Nieuwkoop.

\footnotetext{
${ }^{30}$ In his Secunda Defensio against Westphal Calvin referred back to this and to a further (lost) letter of Dietrich, who had died in 1549, to show that not all "Lutherans" were as hostile to his Eucharistic theology $(C R 9,96)$. This in turn led Dietrich's sons to defend their father's memory, virtuously quoting a reference of his in 1545 (i.e. before the letter of February $3^{\text {rd }}$ 1546 !) to the error Cingli et Calvini, and this line was taken up by Nicholas Selnecker in his Kurtzer Bericht on Dietrich. For the story in detail see Klaus (1958:307-309). If anything, this illustrates only how confused and polemical Lutheran/Reformed relations had by then become, following the Consensus Tigurinus and the second Eucharistic controversy.
} 
Heron, A I C 2005. Wenn Luther uns mit unserem Bekenntnis annehmen will: Luther und die Abendmahlsfrage in den Briefen Calvins bis 1546, in Litz, G, Munzert $\mathrm{H}$ \& Liebenberg, R (Hrsg), Frömmigkeit - Theologie -Frömmigkeitstheologie: Contributions to European Church History: Festschrift für Berndt Hamm zum 60. Geburtstag, 395-409. Leiden: Brill.

Hundeshagen, C B 1842. Die Conflicte des Zwinglianismus; Luthertums und Calvinismus in der bernischen Landeskirche von 1532-1558. Bern.

Klaus, B 1958. Veit Dietrich: Amanuensis D Martin Luthers und Prediger an St Sebald in Nürnberg. Nürnberg: Selbstverlag des Vereins für bayerische Kirchengeschichte.

Krieger, C \& Rott, J (eds) 1995. Martin Bucer: Correspondance, vol 3. Leiden: Brill.

Kuropka, N 2003. Calvins Römerbriefwidmung und der Consensus Piorum, in Opitz, P (Hrsg), Calvin im Kontext der Schweizer Reformation: Historische und Theologische Beiträge zur Calvinforschung. Zurich: Theologischer Verlag.

Opitz, P 1994. Articles in Calvin-Studienausgabe, vol 2, edited by E Busch et al. Neukirchen/Vluyn: Neukirchener Verlag.

Ortmann, V 2003. Martin Bucers Bemühungen um Reformation und Einheit der Kirche bei den Religionsgesprächen 1540/41, in Arnold, M \& Hamm, B (Hrsg), Martin Bucer zwischen Luther und Zwingli. Tübingen: Mohr-Siebeck.

Schwarz, R 1961. Johannes Calvins Lebenswerk in seinen Briefen: Eine Auswahl von Briefen Calvins in deutscher Übersetzung. 3.Auflage. Neukirchen/Vluyn: Neukirchener Verlag.

Stolk, M 2000. Calvin und der Frankfurter Konvent (1539). Zwingliana XXXII, 23-38.

Stupperich, R (Hrsg)1955. 1955. Melanchthons Werke in Auswahl. 6.Auflage. Gütersloh: Bertelsmann.

Van Stam, F P 2000. Die Genfer Artikel vom Januar 1537: Aus Calvins oder Farels Feder? Zwingliana XXVII, 87-101.

Wartenberg, G (Hrsg) 1983. Martin Luther, Briefe: Eine Auswahl, Leipzig: Insel. 